\title{
ХУДОЖНЕ ПОРІВНЯННЯ ЯК ПЕРЕКЛАДОЗНАВЧИЙ ФЕНОМЕН (НА МАТЕРІАЛІ УКРАЇНСЬКОЇ ТА АНГЛІЙСЬКОЇ МОВ)
}

\author{
ОКСАНА МОЛЧКО \\ Львівський національний університет імені Івана Франка, Львів — Україна \\ omolchko@gmail.com

\section{PORÓWNANIE POETYCKIE JAKO FENOMEN PRZEKŁADOZNAWCZY (NA MATERIALE JEZZYKA UKRAIŃSKIEGO I ANGIELSKIEGO)}

OKSANA MOŁCZKO

Lwowski Uniwersytet Narodowy imienia Iwana Franki, Lwów — Ukraina

STRESZCZENIE. Porównanie poetyckie rozpatrywane jest jako fenomen, który odzwierciedla zarówno kognitywne, jak i językowe cechy etnosu. Zastosowując kompleksowe podejście do analizy porównania poetyckiego na materiale nazw roślin, w szczególności hiperonimu kwiat i hiponimu mak, można stwierdzić, iż porównanie to fundamentalny lingwistyczno-kognitywny fenomen, będący odbiciem prawidłowości i relacji między obiektami porównania $\mathrm{w}$ ich językowym odzwierciedleniu. Jest to wynik kognitywnego podziału rzeczywistości, na skutek którego odbywa się zestawienie mentalnych obrazów na podstawie wspólnej cechy; ich werbalizacja według wyznaczonych w systemie językowym zasad gramatycznych, aktualnych modeli z właściwym fonetycznym, morfemowym, leksykalnym składem w konstrukcjach gramatycznych, odpowiednio do subiektywnego postrzegania świata o określonym ładunku funkcjonalnym. Porównanie poetyckie to nieskończoność obrazów, symboli oraz konceptów podlegających adekwatnemu odwzorowaniu w przekładzie.

\section{SIMILE AS A TRANSLATION STUDIES PHENOMENON (A STUDY CASE OF THE UKRAINIAN AND ENGLISH LANGUAGES)}

\author{
OKSANA MOLCHKO \\ Ivan Franko National University of Lviv, Lviv — Ukraine
}

\begin{abstract}
Simile is viewed as a multifaceted phenomenon deeply rooted in cognitive and lingual peculiarities of an ethnos. Applying a complex approach to simile analysis, it being a study casc of the hyponym flower and hypcronym poppy, simile proves to be a fundamental lingual and cognitive phenomenon. It reflects the essential and consistent relationships between the objects of comparison in their lingual form. It is the result of the cognitive segmentation of the outer world whose effect is the comparison of mental images on the basis of a common feature; their verbalization following the corresponding phonetic, morphemic, lexical forms and grammatical constructions with a specific functional load. Simile is the endlessness of images, symbols and concepts to be reverbalised in translation.
\end{abstract}

\footnotetext{
У удожнє порівняння має давню традицію вивчення — від праць давньогрецьких філософів до сучасних лінгвістичних студій. Порівняння Хдосліджують у різних ракурсах — логіко-філософському, структурносемантичному, лінгвостилістичному, лінгвопрагматичному, психолінгвістичному, лінгвоконцептуальному, лінгвокультурологічному, контрастивному та
} 
перекладознавчому. 3 огляду на дослідницькі напрями сформувався багатоаспектний статус художнього порівняння як складної мовної одиниці: 1) у логікофілософському ракурсі порівняння трактують як невід'ємний складник когнітивної діяльності, що репрезентує шлях від порівнювання об'єктів довкілля до їхньої вербалізації; 2) на основі актуалізації структурно-семантичного аналізу виокремлюють моделі основних і допоміжних мовних засобів вираження порівняння. Серед основних — вільні словосполучення (індивідуально-авторські порівняння) в межах простого та складнопідрядного речення з підрядним порівняльним і сталі сполучення слів (фразеологізовані порівняння) у структурі простого та складнопідрядного речення 3 підрядним порівняльним. У будові допоміжних - морфемні (з використанням відповідних способів словотворення no-, -like) та морфологічні (форми орудного та родового відмінків в українській мові); 3 ) художнє порівняння має лінгвостилістичий статус фігури 3 відповідною системою мовної репрезентації; 4) лінгвопрагматика пояснює характерні функції художнього порівняння, що послідовно виявляються в тексті (дискурсі). Взаємодію цих функцій уважаємо обов'язковою умовою успішної мовотворчої та комунікативної діяльності; 5) постулати психолінгвістики, репрезентовані в теорії актуального членування речення, проектуємо на основні типи порівняння, актуалізовані простим та складнопідрядним реченнями 3 підрядним порівняльним; 6) лінгвокультурна й лінгвоконцептуальна семантика порівняння охоплює всі основні та допоміжні засоби вираження порівняння, актуалізує різноманітні поняття матеріального й духовного життя народу та відображається на всіх мовних рівнях. У процесі відтворення культурнозумовленої контекстуальної ієрархії смислів у межах порівняння необхідно ураховувати особливості концептосфери й культури зіставлюваних мов. Разом 3 фразеологізованими, необхідно досліджувати й індивідуально-авторські порівняння, що виявляють специфіку мовотворчої діяльності народу та його окремих представників - митців слова, лінгвокреативних мовних особистостей; 7) ураховуючи зазначені підходи до інтерпретації художнього порівняння, у процесі перекладознавчого аналізу художніх текстів та їхніх перекладів аналізуємо систему способів перекладу та перекладацьких трансформацій, що дає змогу виокремити способи перекладу художнього порівняння, які демонструють особливості мовної репрезентації порівняння в українському й англомовному текстах, та описати наслідки перекладацької діяльності.

Лінгвокультурна сутність художнього порівняння $\epsilon$ нескінченним джерелом для з'ясування універсального й національно-специфічного сприйняття світу, у якому живе людина, та його зіставлення зі світосприйняттям іншого народу на основі аналізу вербалізованих образів, концептів, символів; його вербалізацію в українській та англійській мовах та способи відтворення в перекладі. Національно-культурний компонент інколи виявляється вирішальним в осмисленні поняттєвого комплексу, актуалізованого художнім порівнянням. Флороназви, зокрема, як засіб та результат пізнання природи виконують важливі функції в антропоцентричній площині “людина - природа": людина, іiі риси й дії осмислюються крізь призму образів чи символів, вербалізованих флороназвами. Кольороназви нерідко ускладнюють порівняльні конструкції iз стрижневими компонентами - назвами рослин. Флороназви як компоненти художнього порівняння часто набувають ознак символу, мають свою специфіку: процес перейменування об'єкта відбувається шляхом його переосмислення крізь призму почуттів, емоцій, образних уявлень та оцінок у свідомості етнокультурної спільноти. Художнє порівняння з назвами рослин-об'єктів 
порівняльної конструкції зазвичай ускладнене низкою стилістичних прийомів (зокрема, одиницями фонетичного рівня - консонанс, асонанс та лексикосемантичного - метафора, метонімія, оксиморон, гіпербола, іронія, сарказм). Вони можуть накладатися один на одного, утворюючи ускладнені порівняння з огляду на прагматику та художньо-естетичні функції.

Назви рослин як компоненти порівняльної конструкції складають одну 3 чисельних тематичних груп серед фразеологізованих та індивідуальноавторських порівнянь. Дж. Лакоф стверджує, що одним з найтиповіших зразків структурної метафори є варіант “люди як рослини”. Низку рослинних символів складають назви, що мають біблійну традицію ( $\epsilon$ рефлексією на біблійні образи, серед них гіпероніми квітка, дерево, лист), і національну, позначену етнокультурною специфікою. Образи рослин проходять через усю Біблію, функціонуючи як у буквальному, так і у символічному сенсах. Згідно зі Словником Біблійних Образів, рослини символізують життя в його повноті; минущість життя; і врешті занепад і смерть (“зів'ялі квіти”, “висохла трава”)2.

Образ-гіперонім квітка важливий для мовної свідомості українців. Квіти символізують дітей, дівчат; у Т. Шевченка квітка - символ беззахисності ${ }^{3}$. Назви квітів використовувались як символи язичницьких богів, асоціювалися з іменами християнських святих, стали символами країн, а також елементами загальносвітової, універсальної символіки. Позитивна конотація, що супроводжує цей гіперонім, і в українській, і в англійській лінгвокультурах асоціюється з красою, барвистістю, ніжністю, тендітністю, силою і жагою до життя, а також його швидкоплинністю. У прикладі Дівчата - не розсада, щяоб їх ховати геть од світу ${ }^{4}$ використано порівняння у формі заперечення: письменник підкреслює, що красу не варто приховувати. У перекладі цей образ відтворено способом калькування: The young girls were not greenhouse seedlings to be protected from life 5 . Вербалізований іншою порівняльною конструкцією індивідуально-авторський концепт краса, ускладнений кольороназвою gold, відмінний від типових уявлень, спостерігаємо в зразку He likened her to a pale gold flower upon a slender stem ${ }^{6}$, у перекладі Він порівнював ї̈ з блідо-золотою квіткою на тоненькому стебельиі $i^{7}$ помічаємо підсилення вербалізованого концепту тендітність за допомогою актуалізації граматичної форми зі зменшувальними суфіксами -еньк та -ельц.

Психологічний стан людини, переповненої позитивними емоціями, порівнюється з яскравістю та барвистістю квітів: I can remember how I stood waiting for you in the garden — holding all my self in my arms like a basket of flow$e r s^{8}$. Метафоричність зіставлення вдало відтворено в перекладі: Пам'ятаєте, як я чекала вас тоді в парку? Стояла і тримала саму себе в руках, як кошик квітів ${ }^{9}$. У перекладі зіставлення акцентоване темо-рематично, текст поділено на два прості речення, перше з яких емоційно сильне, у питальній формі. Пауза, актуалізована питальним реченням, виконує естетичну функцію, своєрідного

${ }^{1}$ G. Lakoff, Metaphors We Live By, Chicago 1985, p. 62-63.

${ }^{2}$ Dictionary of Biblical Imagery, 1997, p. 2191.

${ }^{3}$ В. Жай в ор онок, Знаки української етнокультури, Словник-довідник, Київ 2006, с. 280.

${ }^{4}$ Панас Мирний, Хіба ревуть воли, як ясла повні?, [в:] Його ж, Твори, в 7 томах, Київ 1969 , т. 2 , c. 89.

${ }^{5}$ P. Mirny, Do oxen low when mangers are full?, Kyiv 1990, p. 89.

${ }^{6}$ Jack London, Martin Eden, Moscow 1960, p. 21.

7 Джек Лондон, Мартін Іден, [в:] Й ого ж, Твори, в 12 томах, Київ 1971, т. 5, с. 25.

${ }^{8}$ F. S. Filzgerald, Tender is the Night, New York 1986, p. 52.

${ }^{9}$ Ф. С. Фіцджеральд, Великий Гетсбі; Ніч лагідна: романи, Київ 1982, с. 165. 
емоційного катарсису, відображає естетичні цінності персонажа. Пауза в мовленні дає можливість адресантові повідомлення подумати, можливо, оформити свій емоційний ланцюжок.

Красу чоловіка несподівано змальовано засобом зіставлення 3 квітами y вінку, що в українській етнокультурній традиції, особливо відчутній завдяки використанню реалії вінок, вербалізує емоційний концепт краса: ...був високий, огрядний собі пан, кругловидий, русявий; голова в кучерях, як у золотому вінку; очі ясні, веселі, як зорі; і він чи ступить, чи заговорить, то справді погетьманськи ${ }^{10}$. Строкатий одяг татарських жінок, який автор порівнює з квітами, візуалізує образ та вербалізує концепт барвистість: ,... татарки... виглядали звідти, як купки квіток на грядках ${ }^{11}$. Калькування порівняльної конструкції відтворює яскраву гаму авторського світосприйняття в перекладі: ...the Tatar women appeared on the flat roofs of the houses, like clusters of flowers in beds ... ${ }^{12}$.

Сила природи, що виявляється у прототиповому атрибуті швидкий picm рослин, актуалізується в прикладі She detected unguessed fineness in him that seemed to bud, day by day, like flowers in congenial soil ${ }^{13}$, що адекватно відтворено в перекладі: Несподівано вона відкривала в ньому здібності і задатки, щзо день у день розпускалися, як розпускасться квітка на родючому трунті ${ }^{14}$. Навпаки, хвороба, старість і смерть, що мають за основу прототипові уявлення про сухі квіти, як-от у прикладі Зав'яла ти, як садовий цвіток, засохла, як билинка $a^{15}$, відтворено в перекладі способом калькування 3 використанням фразеологізму, розширеного автором: ... уоu have withered like a flower in the orchard, you have pined away like a ruined stock in the field ${ }^{16}$. Підсилення концепту смерть актуалізується використанням паралельних порівняльних конструкцій. Асоціативний ланцюжок квітка - засохла квітка - смерть, що вербалізує концепт минущість життя, утілено в контексті Stephen's heart began slowly to fold and fade with fear like a withering flower ${ }^{17}$, у якому гнітючість образу підсилено й синсемантичним образом на основі консонансу [f] та [w].

Для ілюстрагії багатогранності художнього порівняння 3 компонентомфлороназвою, можливості застосування комплексного підходу до його аналізу та, відповідно, більшої об' єктивності отриманих результатів, до розгляду пропонуємо флороназву мак, що містить і колірний компонент у своїй семантичній структурі.

На відміну від англійської, символіка маку є надзвичайно багатою в українській етнолінгвокультурі: мак - символ пишноти, розкоші; червоний цвіт маку — символ дівочої чистоти, молодості, краси; гарного вбрання; макове зерня символізує все незначне, дрібне: пише як маком сіє; вилетіло як мак, учинилося як шпак; щзоби било як мак, а люде зроблять як сак ${ }^{18}$; недозрілий мак дурманить голову, тому став символом глупоти ${ }^{19}$.

У процесі перекладу цього глибоко символічного образу української етнокультури перекладачі вдаються до різних способів 3 метою його адекват-

${ }^{10}$ П. Куліш, Чорна рада, [в:] Його ж, Твори, в 2 томах, Київ 1989, т. 2, с. 41.

${ }^{11}$ М. Ко цюби н ський, Накамені, |в:| Його ж, Івори, в 7 томах, Київ 1973-1975, т. 2, с. 145.

${ }^{12}$ M. Kotsyubinsky, Fata Morgana and Other Stories, Kyiv 1987, p. 252.

${ }^{13}$ Jack London, Ibidem, p. 84.

14 Джек Лондон, Зазнач. джерело, с. 73.

${ }^{15}$ Г. Квітка Основ'яненко, Маруся, [в:] Його ж, Твори, в 2 томах, Київ 1978, т. 1, с. 103.

${ }^{16}$ H. Kvitka, Marusia, New York 1940, p. 185.

${ }^{17} \mathrm{~J}$. Joyce, A Portrait of the Artist as a Young Man, Wordsworth Classics 1995, p. 82.

${ }^{18}$ Галиизько-руські народні приповідки, у 3 томах, зібрав, упорядкував і пояснив Др. Іван Франко, Львів 2006, 2-ге вид., т. 2, с. 500.

${ }^{19}$ В. Жайворонок, Зазнач. джерело, с. 350. 
ного відтворення цільовою мовою. У прикладах Уляна зардісться, як макова квітка $a^{20}$ та ...(Галя - О. М.) сиділа коло Чіпки, як макова квітка ${ }^{21}$, де ця флороназва актуалізує ознаку дівоча сором'язливість, краса, використано англійське фразеологізоване порівняння, частковий різнообразний еквівалент із збереженням конотативної семантики образу: That would always make her blush like a rose ${ }^{22}$,...(Halya - O. M.) was sitting next to Chipka as pretty as a picture ${ }^{23}$.

Мак в англійців не є прототиповим, як у лінгвокультурі українців, символом сором'язливості, тому калькування автосемантичного образу в прикладі Bid cъого зразу почервонісш, як мак ${ }^{24}$ може спантеличити англомовлянина: You will blush from this stuff like a poppy ${ }^{25}$. У перекладі втрачено символічність образу, яка актуалізує культурно-специфічний смисл в українському контексті.

Відтворення лише денотативної частини значення образу в прикладі Козацтво - як мак ... Жупан червоний, вус чорний, довгий, при бочі шаблюка ${ }^{26}$ без огляду на етномовний символічний компонент може призвести до відчутного спотворення скалькованого образу мак та художнього порівняння, що вербалізує відповідний до його символіки концепт краса. У цьому разі актуалізована в контексті периферійна символічна сема краса може також суттєво змінити сприйняття художнього образу цільовим читачем: Cossaks — like fields of poppy ... Their jackets red, their mustaches black and long, and sabres at their sides ${ }^{27}$. Для британців мак є символічним образом солдатів, які загинули під час двох світових воєн, особливо першої, бо ці квіти росли на полях Франції, де поклало свої голови багато вояків. Люди ж купують червоні паперові макові квітки та носять на грудях у День Пам'яті (11 листопада) на знак пошани до загиблих ${ }^{28}$. Подібна концептуальна підміна символіки та культурно-специфічного смислу не може бути виправдана в жодному разі.

Із метою актуалізації етномовного компонента в перекладі спостерігаємо калькування образу з елементами модифікацій, тобто актуалізації тієї частини семантики образу, що стає ядровою в контексті, як-от у зразку Biн мав дітей, як маку, і ані клаптика поля ${ }^{29}$, побудованому на іронічному ефекті зевгми He had as many children as poppies, but not a bit of land ${ }^{30}$, де актуалізовано прототиповий атрибут багато; або Сказано: зерно, як мачина ...Хоч би насіння вернулося ${ }^{31}$ : у перекладі експліковано лексичне уточнення до основи зіставлення, малий, лексемами small та seeds: I tell you: the grains are as small as poppy seeds. I hope I'll break even getting back what I sowed ${ }^{32}$. У прикладі У просторім душнім класі нормальної школи отців василіян у Дрогобичі тихо, хоч мак сій ${ }^{33}$ фразеологізоване порівняння тихо, хоч мак сій ${ }^{34}$ вербалізує концепт тиша: щоб сіяти мак, українці чекали лагідного безвітряного дня. Перекладач

\footnotetext{
${ }^{20}$ Панас Мирний, Зазнач. джерело, т. 2, с. 126.

${ }^{21}$ Там само, с. 304.

${ }^{22}$ P. Mirny, Ibidem, p. 96.

${ }^{23}$ P. Mirny, Ibidem, p. 267.

${ }^{24}$ Г. Квітка Основ'яненко, Зазнач. джерело, т. 1, с. 89.

${ }^{25}$ H. Kvitka, Ibidem, p. 150.

${ }^{26}$ М. Коцюби н с в к й, Дорогою ціною, [в:] Зазнач. джерело, т. 2, с. 96.

${ }^{27}$ M. Kotsyubinsky, Ibidem, p. 199.

${ }^{28}$ Longman Dictionary of English Language and culture, Pearson 2000, p. 1074.

${ }^{29}$ М. Коцюб и н сь к й, Тіні забутих предків, [в:] Зазнач. джерело, т. 3, с. 83.

${ }^{30}$ M. Kotsyubinsky, Ibidem, p. 53.

${ }^{31}$ Панас Мирний, Зазнач. джерело, т. 2, с. 311.

${ }^{32}$ P. Mirny, Ibidem, p. 274.

${ }^{33}$ I. Франко, Оловець, [в:] Його ж, Зібр. творів, у 50 томах, Київ 1976-1986, т. 15, с. 85.

${ }^{34}$ Галицькко-руські народні приповідки ..., т. 2, с. 500.
} 
відтворив порівняння способом калькування автосемантичного образу, лексично ампліфікуючи його з метою кращого сприйняття англомовлянином: In the spacious Second Grade classroom of the elementary school mun by the Basilian Fathers in Drohobich it was so quiet you could sow poppy seeds ${ }^{35}$.

Беручи до уваги особливості флороназви мак в українській та англійській мовах, з'ясовано, що референтом цієї флороназви є рослина: мак - рорру. В основі образного уявлення - макова квітка / макове зерня - рорру flower / poppy seeds. Прототиповими конвергентними атрибутами є колір (червоний) colour (red); дивергентними, властивими лише українській лінгвокультурі розмір / кількість / природні умови / властивості.

Унаслідок аналізу лексикографічних та літературних джерел з'ясовано, що в українській лінгвокультурі мак частіше виявляє прототипові позитивні асоціативні атрибути краса / молодість / сором'язливість / невеликий розмір, хоч сема кольору, червоний, та відповідно, вербалізація концепту смерть, кров також присутня, але значно рідше. В англомовній свідомості мак символізує загиблих солдат у І Світовій війні, тому назнак пошани й смутку носять на грудях макову квітку. Виявлена концептуальна розбіжність культурно зумовлена, тому невиправдане калькування художнього порівняння в перекладі нерідко може призвести до підміни концептів, а саме українських культурних концептів краса / сором'язливість / малий розмір / велика кількість / тища. Спільні концепти, кров /смерть — blood / death не викликають труднощів ревербалізації.

У процесі відтворення вербалізованого концепту, актуалізованого художнім порівнянням, застосовуються (а) головно, компенсаторні засоби, що вербалізують концепт за допомогою інших образів із спільним атрибутом. Це викликає суміжні асоціації внаслідок застосування калькування як способу перекладу та очуження як виду перекладу. Рідше (б) вербалізується відповідний концепт цільової мови за допомогою ідентичного образу зі спільним атрибутом унаслідок застосування уподібнення, тобто повного (часткового) еквівалента як способу переклалу, та адаптапії як виду переклалу.

Перекладознавчий аналіз художнього порівняння базується на застосуванні низки підходів. 3'ясовано, що калькування образу - найчастотніший серед зазначених способів відтворення порівняння. Пояснюємо це специфічним етнокультурним наповненням образу, його мовним утіленням, особливостями семантики лексем-конституентів та символіки. Усе ж, дотичність лінгвокультур виявляється в досить частому відтворенні порівняння частковим та повним еквівалентами.

Художнє порівняння - фундаментальне лінгво-когнітивне поняття, що відображає сутнісні, закономірні зв’ язки й відношення між об'єктами зіставлення в їхньому мовному втіленні. Це результат когнітивного членування дійсності, унаслідок якого відбувається зіставлення ментальних образів на основі спільної ознаки, їхня вербалізація за встановленими в мовній системі граматичними ıравилами, чинними моделями, 3 відновідним фонетичним, морфемним, лексичним наповненням, у граматичних (морфологічних i синтаксичних) конструкціях відповідно до суб'єктивного бачення світу конкретною мовною особистістю / мовним колективом), 3 певним функційним навантаженням, у нескінченності образів, символів та концептів, що підлягає відтворенню в перекладі, інтерпретуванню в процесі перекладознавчого аналізу з метою виявлення адекватності відтворення в цільовому тексті чи надання рекомендацій щодо ефективнішого способу відтворення розглянутих мовних одиниць.

${ }^{35}$ I. Franko, Short stories, Kyiv, 1977, p. 189. 